The Open Family Studies Journal
CrossMark
Content list available at: www.benthamopen.com/TOFAMSJ/
DOI: $10.2174 / 1874922401608010001$

\title{
The Lived Experiences of Children in Care with the Going Home Process in a Chinese Context: An Exploratory Study
}

\author{
Mooly M. Wong* \\ Department of Social Work the Chinese University of Hong Kong Shatin, New Territories, Hong Kong
}

\begin{abstract}
:
Aim:

This study revealed, through their narrations, the changes in the lived experiences of children who resided in residential childcare services regarding the going home process in a Chinese context.
\end{abstract}

\section{Methods:}

The research design is that of a panel study of a qualitative nature. Eight children, aged from 9 to 18 , were interviewed at three different points during the process of going home. The data were collected through in-depth interviews, supplemented by the use of reflective photography. Data were analyzed by three narrative approaches - macrostructure, plot development and theme.

\section{Results:}

The findings indicated that the children's lived experience with the going home process was a path of stabilization, which meant that their sense of control over their lives was increasing from the first to the second to the third wave of data collection. The children's stories were progressive, with their narrations characterized by advancement. Three themes, namely "uncertainty", "restoration" and "challenge", emerged at three points in time, with distinctive concerns and feelings occurring in each stage.

\section{Conclusion:}

Their experiences reflected the dominant discourses on children, particularly on disadvantaged children such as children in care. These children are constructed by Chinese society as innocent, lacking knowledge and powerless culturally and socially. Alternative discourses on children as knowledgeable, resourceful and active agents were identified in this study, which shed light on child welfare policy and practice.

Keywords: Child welfare, Children in care, Chinese, Going home, Narrative, Social constructionist framework.

\section{INTRODUCTION}

The family reunification of out-of-home care children refers to physically reuniting children with their birth families or relatives [1,2]. An abundance of empirical studies have examined the risk and the protective factors involved in family reunification, such as children's characteristics [3 - 8]; family characteristics [9 - 17]; and services characteristics $[5,9,12,18,19]$. The purpose of these studies was to identify the circumstances that lead to successful and unsuccessful outcomes in order to provide insight to policy makers and child welfare practitioners regarding predicting the outcomes of various policies.

However, these studies might overlook the fact that the outcomes of family reunification are not influenced by a single factor but involve multiple levels and inter-related events within the process. Sinclair (2005) [20] studied the

\footnotetext{
* Address correspondence to this author Department of Social Work the Chinese University of Hong Kong Shatin, New Territories, Hong Kong; Tel: (852) 3943-7514; Fax: (853) 2603-5018; E-mail: mcwong@swk.cuhk.edu.hk
} 
overall outcomes of fostered children and determined that how children got into a care system, how placement was working currently, and how their outcomes occurred, should be matters of concern. For example, the degree of the impact on the quality of prior placements affecting the experiences of children in subsequent placements or returning home, and the extent of the support rendered by the substitute caregivers of placements after children have left a care system, has an effect on the children's adjustment when they return home.

Furthermore, family reunification occurs in a specific context [21 - 23]. For instance, Biehal (2007) [21] analyzed the changes in the profiles of children in care since the introduction of the 1989 Children Act in England. The Act has raised the thresholds for admission while allowing children to stay longer in the care system because most of them were severe cases. The study of Sinclair, Baker and Lee (2007) [22] and Wade, Biehal, Farrelly and Sinclair (2011) [23] further supported the idea that the low success rate of family reunification was closely related to the nature of the case due to the admission thresholds, and in return, affected decision making regarding family reunification. Therefore, whether or not children could return home was not solely determined by individual and family situations, but also shaped by local policy and practices that were underpinned by the considerations of management and professionals.

Hence, family reunification should be viewed as a process and viewed in context. The elicitation of the lived experiences of the involved parties such as the children, caregivers and social workers with family reunification are able to show the inter-relationships of events occurring within the process and its context. The lived experiences of the children are particularly important partly because the children are the primary service users, and partly because there is still a lack of studies listening to and amplifying their voices [24, 25]. Holland (2009) [26] reviewed 44 peer-reviewed articles, published from 2003 to 2008, on children's perspectives on their general care experiences and a wide range of substantive issues such as education, mental health services, contact with relatives and advocacy etcetera. Surprisingly, none of the reviewed papers was on family reunification. At present, there are only a few studies published in books that reveal family reunifications from the perspectives of the children [2, 20, 22 - 23]. No such study has been conducted in Hong Kong. In view of the scarcity of research overseas and the woeful lack of such a study in a local context, the author conducted a panel study of a qualitative nature from 2012 to 2014 as her PhD dissertation. The study was approved by the Survey and Behavioural Research Ethics Committee of the university. Situated in a social constructionist framework, this study aimed at exploring, through their narrations, the lived experiences of children who resided in residential childcare services, and their caregivers, during the going home process in a Chinese society. This paper will report on the research done on the children's experiences.

\section{FAMILY REUNIFICATION IN A SOCIAL CONSTRUCTIONIST FRAMEWORK}

This study, set within the framework of social construction as previously mentioned, used the term " going home ". Social constructionists deny there is an "objective truth" that is pre - existing and can be revealed by observation [27 - 29]. Instead, realities are socially constructed, and these are multiple, apprehensible and sometimes conflicting [30]. Hence, the term "going home" is used in the study, in order to minimize the single and the pre-determined meaning of the term "reuniting with the family". Like other social phenomenon, in this study, "going home" for children in care is a meaning making process that is constructed by the interactive effects of a specific time and contexts.

The study conceptualized this phenomenon with respect to four aspects: (a) socially constructed; (b) situated in social contexts; (c) non-static and changing; and (d) shaped by language and practices.

Time is categorized into different stages in the going home process, i.e., the pre-placement, placement and post placement periods. Contexts refer both to micro-contexts - family, school and care facility, which have direct impacts on the experiences of the children - and to macro-contexts, such as the ideology of child protection system. Instead of identifying the consistencies in their experiences, the study focuses on identifying the changing meanings of going home that are revealed by the children's distinctive emotions, struggles and concerns during different stages through their language, i.e., their narrations. An analysis of the changing meanings of the narrators can show the "forms of life" in society [30]. In other words, the children's stories during the going home process are able to identify the social practice that is prevalent in society, i.e. the dominant social discourses such as those on children, the family and child protection. Meanwhile, some alternative discourses can be achieved through dialogue, and the process of relational coordination [30, 31]. The dominant social discourses give way to the development of new realities, rationalities, values and practices and a new discourse is formed. 


\section{FAMILY REUNIFICATION IN HONG KONG}

In Hong Kong, most of the child welfare services were started by charitable organizations and religious groups late in the $19^{\text {th }}$ century. It was not until the mid-60s that the government took a clear direction in child welfare policy. The stance of the government shows clearly that the responsibility for childcare should lie with the family and the government is to provide minimal intervention unless the children are at risk [32 - 35]. The role of residential childcare services is to provide alternative and temporary care for children and adolescents under the age of 21 who cannot be adequately cared for by their own families due to a personal or family crisis [36, 37]. The services aim at ensuring that children are able to enjoy family life while a permanency plan is being worked out for them [38].

Three thousand one hundred and eighty-eight children were living in these care facilities as of December 2014, which was around $0.2 \%$ of the child population aged $0-19$ in Hong Kong. Compared with other places like Australia, England, and the USA [39], the number of children in care was relatively low, but the reasons for admission were quite similar. Ninety-nine percent of the children were removed from their homes due to family problems including inadequate parenting (28.92\%), child abuse (12.81\%) and their parent's having mental problems (10.8\%) [40].

The majority of the children are admitted to three types of residential childcare services: foster care families, small group homes and children's homes. As of December 2014, these children spent an average of 28 months in care facilities [41]. Moreover, the number of children who have resided and been discharged from care facilities has been steady over the past few years. For instance, there were approximate 886, 932, 939 and 926 children living with foster families in 2011, 2012, 2013 and 2014 respectively [42 - 44]. Of these children, in the above mentioned years, 506, 489, 439 and 429 children respectively had left their foster families due to one of these reasons: had been reunited with family, admitted to other types of residential care services, adopted or were living independently [41]. During these four years, on average, only slightly above half of them (55\%) were reunited with their families. Thirty-four percent were admitted to other residential care placements, $10 \%$ were adopted and $0.3 \%$ were living independently [41].

Although the government emphasized the temporarily nature of the services, and family reunification is the most desirable outcome for children in care, the current situation with children spending a considerable period in care facilities and with a relatively low rate of family reunification may reflect the situation that family reunification is not a straightforward issue.

\section{METHODOLOGY}

\section{Research Design}

The research design is a panel study of a qualitative nature, with a combination of retrospective and prospective approaches. Children were interviewed at three points in time - within 9 months before the tentative date of return, and then two months and five months following the original tentative date of return respectively. The date of return was termed "tentative" as an exact date of return was often still uncertain at the time of the first interview. This was another area of negotiation for the children, their caregivers and the social workers (both the referring social workers and the residential childcare / foster care social workers). These three points in time were chosen because they were situated in distinctive contexts with respect to the physical setting (i.e., either at care facilities or at home) and the situations (i.e., they were living with substitute caregivers or birth families).

\section{Sample}

Purposive sampling [45] was used in this study. Eight children were recruited through the referrals of social workers of non-government organizations that rendered residential childcare services. Table 1 shows that the children were mostly female $(n=6)$ and teenagers, i.e., aged 13 or above $(n=5)$. The youngest informant was 9 years old, and the oldest was 17 years old. Two of them were in elementary school, and the others were in secondary school $(\mathrm{n}=6)$. All children had siblings, either natural $(n=6)$ or step $(n=2)$, who were living either at home with caregivers $(n=2)$, in care facilities $(n=3)$ or independently $(n=3)$. All children were admitted to their current care facilities due to family issues, including receiving inadequate care from their caregiver $(n=4)$, child abuse $(n=2)$, parent-child relationship problems $(\mathrm{n}=1)$ and sibling violence $(\mathrm{n}=1)$. The majority of the children were residing in small group homes $(\mathrm{n}=7)$ and the rest with a foster care family $(n=1)$. Half of the children $(n=4)$ had experienced one admission, and the rest had experienced two $(n=3)$ or three $(n=1)$ admissions. Over half of the children had lived in their current care facility for four years or less $(n=5)$. The shortest duration of residency was 2 years $(n=2)$. The others $(n=3)$ had been living in their present care facility for more than 5 years, with 11 years being the longest duration. When the duration of 
previous placements was counted, the majority of informants $(n=6)$ had been living in care facilities for 5 years or more, and the rest, 1 to 2 years $(n=2)$. Two children were diagnosed with a mental illness before admission, namely oppositional deficit disorder (ODD), and attention deficit and hyperactivity disorder (ADHD). One child had muscular dystrophy and had been a slow learner since birth. The other five children had no special issues.

Table 1. Profiles of the children $(n=8)$.

\begin{tabular}{|c|c|}
\hline & Number \\
\hline \multicolumn{2}{|l|}{ Sex } \\
\hline Male & 2 \\
\hline Female & 6 \\
\hline \multicolumn{2}{|l|}{ Age } \\
\hline $9-10$ & 1 \\
\hline $11-12$ & 2 \\
\hline $13-14$ & 3 \\
\hline $15-16$ & 1 \\
\hline $17-18$ & 1 \\
\hline \multicolumn{2}{|l|}{ Education } \\
\hline Primary & 2 \\
\hline Secondary & 6 \\
\hline \multicolumn{2}{|l|}{ Siblings } \\
\hline Natural & 6 \\
\hline Step & 2 \\
\hline \multicolumn{2}{|l|}{ Living arrangement of siblings } \\
\hline At home & 2 \\
\hline At care facility & 3 \\
\hline Living independently & 3 \\
\hline \multicolumn{2}{|l|}{ Reasons of admission } \\
\hline Inadequate care & 4 \\
\hline Child abuse & 2 \\
\hline Parent-child relationship & 1 \\
\hline Sibling violence & 1 \\
\hline \multicolumn{2}{|l|}{ Current types of placement } \\
\hline Small group home & 7 \\
\hline Foster care family & 1 \\
\hline \multicolumn{2}{|l|}{ Number of admissions } \\
\hline 1 & 4 \\
\hline 2 & 3 \\
\hline 3 & 1 \\
\hline \multicolumn{2}{|c|}{ Duration of residency in current placement (year) } \\
\hline $1-2$ & 4 \\
\hline $3-4$ & 1 \\
\hline $5-6$ & 2 \\
\hline $7-8$ & 0 \\
\hline $9-10$ & 0 \\
\hline 11 or above & 1 \\
\hline \multicolumn{2}{|c|}{ Total duration of residency (previous and current) (year) } \\
\hline $1-2$ & 2 \\
\hline $3-4$ & 0 \\
\hline $5-6$ & 1 \\
\hline $7-8$ & 3 \\
\hline $9-10$ & 1 \\
\hline 11 or above & 1 \\
\hline \multicolumn{2}{|l|}{ Mental/Physical illnesses } \\
\hline Mental & 2 \\
\hline
\end{tabular}


(Table प) contd......

\begin{tabular}{|l|l|}
\hline & Number \\
\hline Physical & 1 \\
\hline No special problem & 5 \\
\hline
\end{tabular}

The profile showed that the majority of the recruited children were 13 years old or above $(n=5)$ and resided in small group homes $(n=7)$. The researcher (the author) intended to recruit more young children (i.e., 6 to 10 years old) and children residing in other types of residential care services such as foster care, but no such referrals were received. Local statistics show an interrelation between age and type of placement, such that young children are very often placed in foster care [41]. The low referral rate for young children and children living in foster care can be explained by two factors. First, adults such as social workers, parents and lawyers usually are the gatekeepers and they may worry about the negative impact of research on young children. Second, some empirical studies have shown that some social workers may be hesitant to return younger children to their families [9], which might be relevant in the local circumstance. Therefore, most of the children recruited for this study were older and lived in small group homes.

Another important point in the children's profile is the duration of the residency. Four out of 8 children had been living in the current care facilities for 2 years or less, which is the average duration for children in care as indicated by official statistics. However, when the residency periods during previous placements were counted, there were only 2 children who had lived in care facilities for less than 2 years in total. The majority of the children had been in care for over 5 years. Most entered care at a very young age and had lived for an extended period in care facilities. This also implied that the going home process might become harder or more complicated with the passage of time $[5,18]$.

\section{Data Collection}

Semi-structured in-depth interviewing [46 - 48] was adopted in this study. Reflective photography [49], a method that uses photographs to help stimulate an interviewee to open up during a research interview, was used as a supplementary method to facilitate and enrich the children's narrations. Thirty interviews, including 16 supplemented with reflective photography, were conducted during three waves of data collection. The number of interviews with each child in the three waves of data collection varied, ranging from 3 to 6 interviews, depending on their ages and the richness of their stories. It took more time for the researcher to engage with the young children and facilitate interviews with them. Some children's stories were so rich that the child might feel too overloaded trying to relate it all during just one interview. Interview guidelines that included introspective and retrospective questions were prepared for the interviews. Most questions emerged from the dialogues between the researchers and the informants rather than in response to pre-set questions.

\section{Data Analysis}

The data were transcribed by converting the interviews verbatim from audio tape to written Chinese. Each transcription was re-read several times before selecting the narrative segments and re-constructing the narrations [50]. The re-constructed narrations adhered closely to the perspectives of the children, particularly the meanings of the stories. The re-constructed stories were compared and then analyzed by three narrative approaches - macrostructure [51, 52], plot development [53] and theme [54]. The macrostructure is concerned with the focal point and "who is doing what to whom", i.e., the character, plot and time of a story. Plot development is focused on the overall change in the macrostructure of the children's stories across the three waves of data collection, which may be (1) progressive, a course of advancement, achievement and success; (2) regressive, a course of deterioration and decline; (3) stable, with no evidence of either progression or decline. The thematic approach was adopted to analyze the common elements that emerged in the plotlines across the narrations of the children.

\section{Ethical Issues}

All children joined the study voluntarily. They understood that they had full freedom to withdraw from the study if and when they wanted to. Written consent was obtained from the children's parent / guardian. Children aged 6 to 11 are able to read simple wording [55] and so a simplified version of the consent form was prepared for the children. The children were given sufficient information about the purposes of the study to ensure that there was no deception. Apart from that, the researcher paid special attention to the issue of power imbalance between herself and the children because the inherent adult-child relationship might lead to the views and the perspectives of the researcher unduly coloring the perspectives of the children $[56,57]$. The researcher always adopted a reflective attitude during the interview process. 


\section{RESULTS}

The findings indicated that the children's lived experience with the going home process was a path of stabilization, which meant that the children's sense of control over their own lives was increasing from the first to the second to the third wave of data collection. The children's stories were progressive, with their narrations characterized by advancement. Three themes, namely, "uncertainty", "restoration" and "challenge" emerged that described the changing concerns, struggles and emotions of the children at those three points in time.

\section{Uncertainty}

In the first wave of data collection, the theme "uncertainty" was identified. The children were interviewed at the time when the children, their parents and the social workers (referring social workers and residential childcare social workers) were negotiating the children's discharge from the childcare facility. It was the focal event of the narrations and the temporal arrangement of the stories was in the future - the predication of the outcome of the negotiation. The central characters were people that were influencing the outcome of the discharge including parents, the staff of care facility and social workers.

All the children were struggling with the expected outcomes of the discharge because they felt extremely helpless and powerless with respect to the process and the result. They had taken clear stances on the discharge and justified the reasons for wanting or not wanting the discharge with substantiated grounds. Six children expressed their desire to return home due to the undesirable environment in care facility and their wish to repair their parent-child relationship. Two children who were ambivalent about their mothers wanted to remain in the care facilities. For instance, Donald (all the names used here for the children are pseudonyms), a 15-year-old teenager, narrated his eagerness to return home due to the deprivation of freedom he experienced when he lived in a care facility.

"There was staff who accompanied us to buy clothing. I never liked the clothing that they bought. I really despised it. So I threw away almost all the clothing...they wouldn't give us money and let us buy things by ourselves... Yes, the money was mine, but they wouldn't give the money to me... They wouldn't let us choose our clothing. They commented that the clothing was either too expensive or too stylish. Anyway, they made so many comments that I just gave up...Actually, we just have different taste."

Alice was an 11-year-old girl who hesitated to return home. On one hand, she commented on the rules in the care facility in a less harsh way than Donald did.

"I can put my feet on the chair when I am at home, but I can only play computer games for around 15 to 45 minutes at the small group home. However, I can play computer games for the whole day if my mom is not at home." (Researcher: Which place gives you more freedom?) "It is hard to tell."

On the other hand, Alice made very negative comments about her mother:

Well, I think I would not be condemned by others as seriously (when I live in the care facility). Also, I would not be punished by others as frequently...My mother forces me to kneel down as punishment; Madam X (the houseparent) also punishes me but she only asks me to do household chores for a day...Mother punishes me, making me stand still, copy sentences, kneel down, etc... Madam X also punishes me, but not as much as my mother does.

Nevertheless, all of them expressed the opinion that adults (e.g., caregivers and social workers) dominated the decision-making process and they had no say in it at all, or adults did not listen to them sufficiently. For instance, Judy, a 15-year-old girl who wanted to return home very much, regarded that there was a clear power hierarchy between her, her mother and the residential childcare social worker.

"Ms. X (the residential childcare social worker) was the chief commander, the commander at the back...Actually, we are soldiers...She (My mother) is a senior soldier and I am a junior soldier... They (the residential childcare social worker and the referring social worker) make all the decisions. I couldn't say no even though I was reluctant. I had no control over it."

William, a 12-year-old boy, shared the same feeling. He narrated:

Why would they [social worker and his father] listen to me? They only listen to adults.

The strong sense of having to remain passive caused much disturbance in the children during the process of negotiating the discharge. For example, Mandy, who was a 17-year-old girl, had lived in a care facility for 11 years. Although she was approaching the age limit of the care facility and expected to return home very soon, she was 
reluctant about the arrangement. She used a photo of a cloudy sky to describe her feelings at that stage.

"I was highly disturbed by the issue of my return, like the clouds. I had many worries at that time. Was there any hope? I really did not know. I felt so confused and didn't know what to do."

\section{Restoration}

The theme of "restoration" emerged in the second wave of data collection. By that time, six children who had previously expressed their desire to return home had returned home. Two children wanted to stay in the care facility but only one child (Mandy) was granted an extension to their period of residency. Another child, Alice, returned home reluctantly. Regardless of the outcome of the discharge, the negotiation process was ended. The children were gradually resuming their daily lives like the majority of children and youth. The focus had shifted from their discharge to their family and school life - their immediate concerns and the central characters were now family members, schoolteachers and peers at school.

In this stage, even though the children faced different adjustments and challenges in family and school life, they regained autonomy over their lives and showed resourcefulness in coping with the challenges. For instance, Cathy, a 12-year-old girl, felt that her mother had abandoned her to the care facility. After her return, she initiated a serious talk with her mother and ultimately resolved the issue:

Time flies, over two years. I was very unhappy when I first got there. I had many grievances with my mother. Why did she send me there? She could have stopped it. I asked her this question many times, but she didn't answer me. A week after I got home, I asked the same question again. She told me that she had had no choice. The social worker forced her to make that decision; she could not say no. I understood fully after that. I realized that I should not blame her, and I began to regret what I had done to her before.

Alice, who returned home unwillingly, faced a great challenge at this stage. She described her feelings as "happy and angry".

"The first month I was home, I would please my mother if she scolded me. I would say, “Mommy, don't be so mean. Madam X (houseparent) didn't treat me like this." Then, my mother would be silent. Later, my mother started to say that I was not Madam X's daughter, and that's why Madam X did not pay attention to me. So that strategy was useless... When I feel angry, I argue with her... I felt angry after just being home for a month...I thought it was okay to live at home during the first month, but it wasn't as happy as in the small-group home. I think it is somewhere between happy and sad."

Notwithstanding the above, Alice knew that it was useless to keep arguing with her mother. Alice started using different strategies such as superficial compliance and secret disobedience to cope with the demands of her mother. She found that the strategies were workable, at least to minimize the nagging of her mother.

"I know that if I study, she will stop nagging me...yes, I should study. But I don't feel like studying when she scolds me. So I just pretend to study...I don't want her to nag me anymore."

The children's resourcefulness was also demonstrated in their adaptation to school life. For example, Cathy, who had disliked studying very much before lived in a care facility, indicated that she was determined to start a new page in her life.

"Yes, I worried about it (travel time). I kept on telling myself that I had to wake up and leave home punctually so that I wouldn't be late for school...It is not a matter of one or two days. I had to keep at it for a week. I was worried when the school term started. Actually, I do not have any friends who have to wake up so early. They usually wake up at 7 a.m., not as early as 6 a.m."

Before her discharge, Alice also worried about school life because she would be studying at the same primary school she had attended before living in a care facility. Although no classmate knew that she had lived in a care facility during her absence from school, she did not want her previous classmates to recognize her. She told the researcher about her coping with the situation, which was strategic and tactful.

"I wore a medical mask on the first week of school. A teacher noticed that and asked me if I was really sick... Then I didn't wear it later...I looked down when I met them (previous classmates) ...Yes, they wanted to talk to me...I turned my face away from them immediately. Some of them could not see me, and some just passed by me...Moreover, I would not go down to the playground during recess..." 


\section{Challenge}

In the third wave, the theme of "challenge" was revealed. Seven children had returned home for 5 months. Their family life and school life were becoming stable. Unlike in the previous stages, this time their main concern was about their future, which was also the focus of their narrations. Even though they understood that their plans were tentative and predicated great difficulties in achieving them, they were energetic and hopeful about the future. The central characters were their family members and school related persons - the people that motivated them to pursuit their dreams. For example, Sophia shared that she wanted to be a chef because she thought it would be meaningful to herself and to her mother.

"I want to be a chef when I grow up. I mean... a chef making Japanese food...because both my mother and I like sushi very much. I want to be a chef and open a sushi restaurant."

Mandy focused on preparing for the public examinations. Encouraged by her teachers, she worked very hard and believed that it was the only way to change her fate.

"I started to ask myself: "Why should life be so hard"? I have some questions about this. What is the meaning of studying? ...Actually, I want to change...I don't like the status quo. I don't like my present life...I want to have some achievements. I mean, I want to study in a university because I don't want to live on welfare forever."

The themes of "uncertainty", "restoration" and "challenge" characterized the process of "going home", i.e., a path of stabilization. At the first phase of data collection, the children were struggling with the possible outcomes of the discharge. The children felt helpless and powerless because they had no control over the result. The theme of the second wave was described as "restoration" because they felt settled and autonomous and they showed resourcefulness when facing their situations. In the third stage of data collection, the theme of "challenge" emerged. Although the children narrated their plans in an uncertain manner, they regarded the future as bright and rosy. Their plans also became the driving force to move on in their lives.

Social constructionists propose that the way to re-construct "realities" is through the emergence of alternative discourses in dialogue. In this study, alternative discourses showing the children to be knowledgeable, resourceful and active agents are identified from their narratives. The stories began when the children expressed their grounds for returning or not returning home, showing that they have a thorough understanding of the situations in care facilities and in their families as indicated in the narrations of Donald and Alice. Nonetheless, professionals and caregivers muted the children's voices. Their potential began to unfold as their lives became more stable. This study indicates that children are resourceful in coping with challenges at home and school, and that they have many different strategies to cope with challenges at home and at school as shown in the case of Alice and Cathy. Once their lives settled down, they had the ability to cope with developmental demands such as family relationships, peer relationships and academic demands, and plan their futures, similar to the majority of children in society.

\section{DISCUSSION}

The findings of this study show that children, particularly disadvantaged children such as children in care, are constructed as being innocent, lacking knowledge and being powerless - the dominant social discourses on children in Chinese society. These dominant discourses are reflected in the cultural and the social policy aspects of Hong Kong.

Culturally speaking, Chinese people believe in the purity of children, which could be connected to the notion that "children are like a blank sheet of paper". This assumed purity implies that adults have an obligation to protect and rescue children from the corruption of the world by providing security and protection [58 - 61] and by educating them and fostering their lives. In addition, children are powerless because they are perceived as immature and incomplete $[60,61]$. It is particularly true in Chinese culture because interpersonal relationships are conceptualized hierarchically as arranged in the Five Cardinal Relationships [62]. For instance,children always have a junior position and have the least power in the family hierarchy no matter how old they are. The notion of "not being grown up forever" is common among parents, which implies that children are perceived as not yet ready to be adults and not mature enough to take up adult responsibilities [62].

Apart from that, the social system shapes the dominant discourses on children. As children are minors in society, their rights are represented by adults as is shown in ordinances such as the Guardianship of Minors Ordinance (Cap.13) [63]. Moreover, children are represented by their parents, guardians or professionals when using services such as Legal Aid and the Office of the Ombudsman etc. [64]. The underpinning philosophy of these practices is the principle of best 
interest. For instance, the Guardianship of Minors Ordinance states that if children are involved any court proceedings, the court must consider the children's welfare first [63]. Other factors such as the wishes of the children or the parents, the age or sex of the children, or the conduct of the parents are secondary to what the court finds is in the children's best interest at all times. This implies that the court has the ultimate power and authority to represent the best interests of the children.

Apparently, the cultural beliefs and the social value of children influence the practices of child welfare practitioners involved in residential childcare services in Hong Kong. Parents with children residing in care are perceived to be incompetent caregivers as they have failed to perform their roles effectively and properly. Therefore, child welfare practitioners are delegated by the social system to take up the responsibility of ensuring the welfare of children. The best interest principle is an approach commonly adopted by child welfare practitioners when they make decisions regarding children's welfare. Nevertheless, this principle of best interest has many problems, such as a lack of clear guidelines, undermining the power dynamics among adults, overlooking the long-term negative impacts on children of any decision chosen, and ignoring the overall needs of the family [65].

Besides the above, residential childcare workers who perceived children as powerless adopted a behavioral management approach in the form of supervision, control and constraint. As a result, the children's voices were further suppressed as indicated in the discharge-negotiation process. Even worse, this limits the children's resources and potential.

The alternative discourses of children as knowledgeable, resourceful and active agents imply that children are able to make decisions on their own. They shed light on child welfare policy and practice.

With respect to child welfare policy, the local government has already formulated some measures to maximize children's involvement. For instance, in the issue of custody care and guardianship cases, the court may listen to the wishes of the children through the social workers of the Child Custody Services Units. The social workers encourage the children involved in such cases to express their views on custody and access arrangements. In the investigation process during child protection cases, the children's involvement is ensured through the use of videotaped interviews conducted in private suites [66]. If children need to give testimony in court proceedings, they are provided with a Witness in Court leaflet for their information. Remote conferencing via video feeds and support persons are arranged for children as well [66]. In addition, in 2006, the first child-led organization, the Kids' Dream, was established, aimed at promoting and increasing public awareness of the rights of children and actualizing the concept of "children speaking for children" [67]. A report that reflected the views of children on welfare issues was published in 2012 [68].

Notwithstanding, these are only some good practices and have no legal enforcement. The impact of children's views on child welfare policy remains unclear. This reflects the fact that the government is still hesitant to treat the participation of children in child related issues as their right. It is worthwhile to actualize the participatory rights of children by establishing formal channels. For instance, like the promulgation of the "Patient Charter" by the Hospital Authority of Hong Kong [69], the rights of children in care should be actualized by the establishment of a "Charter for children in residential childcare services". In order to ensure that children have sufficient participation and involvement in childcare services, the Charter should state clearly the rights of children in care including the right to survive, to develop, to participate, and to be protected from discrimination .

In child welfare practice, practitioners should be aware of the use of power as delegated by the system. The misuse of power might result in the suppression of the voices and potential of the children as indicated in this study. Power should be used contextually, having a regard for the age of the children and the situations in question. Child welfare workers will still need to use their protective power in order to safeguard young children who are in danger. Still, even in this situation, the worker should strive for a respectful, open and co-operative relationship with the children and their family members. As in the case of the negotiation of a discharge, social workers should actively engage the children and the family so that they are working together as partners who are relatively equal in status.

\section{CONCLUSION}

The findings show clearly that the practice of residential childcare services in Hong Kong is constructed by the dominant discourses on children that portray them as innocent, lacking knowledge and powerless in Chinese society. Adults such as professionals and caregivers overlook the views of children easily, which is indicated in the negotiation process of discharge of children from the care facility. The children's agency over their own lives unfolded gradually when the children were no longer bothered by the possible outcomes of the discharge. Alternative discourses portraying 
children as knowledgeable, resourceful and active agents emerged in this study, which provides valuable insight for policy makers and practitioners in relation to child welfare. Although the study has several limitations including the lack of generalizability of the findings due to the small sample size, the over-representation of teenagers who lived in small group homes, and the time available being insufficient for a long engagement with the respondents, it is a pioneer work. The study can fill a knowledge gap in family reunification and can enrich our understanding of the going home process in a Chinese context. Most importantly, amplifying the voices of children and involving them in child welfare research can help us as adults to avoid limiting our thoughts, to open up a new way of thinking differently and ultimately to act in new ways.

\section{CONFLIECT OF INTEREST}

The authors confirm that this article content has no conflict of interest.

\section{ACKNOWLEDGEMENTS}

Decleared none.

\section{REFERENCES}

[1] Bullock R, Little M, Millham S. Going home: The return of children separated from their families. England: Dartmouth Publishing Company Limited 1993.

[2] Bullock R, Gooch D, Little M. Children Going Home: The re-unification of families. England: Ashgate Publishing 1998.

[3] Carlson B, Smith C, Matto H, Eversman M. Reunification with children in the context of maternal recovery from drug abuse. Fam Soc J C Soc Serv 2008; 89(2): 253-63. [http://dx.doi.org/10.1606/1044-3894.3741]

[4] Cheng TC. Factors associated with reunification: A longitudinal analysis of long-term foster care. C Y Serv Rev 2010; 32(10): 1311-6. [http://dx.doi.org/10.1016/j.childyouth.2010.04.023]

[5] Delfabbro P, Barber J, Cooper L. Predictors of short-term reunification in South Australian substitute care. Child Welfare 2003; 82(1): 27-51. [PMID: 12641377]

[6] Hines AM, Lee PA, Osterling KL, Drabble L. Factors predicting family reunification for African American, Latino, Asian and White families in the child welfare system. J Child Fam Stud 2007; 16(2): 275-89. [http://dx.doi.org/10.1007/s10826-006-9085-2]

[7] Pine BA, Spath R, Werrbach GB, Jenson CE, Kerman B. A better path to permanency for children in out-of-home care. C Y Serv Rev 2009; 31(10): 1135-43.

[http://dx.doi.org/10.1016/j.childyouth.2009.07.006]

[8] Wulczyn F. Family reunification. Future Child 2004; 14(1): 94-113.

[http://dx.doi.org/10.2307/1602756] [PMID: 15072020]

[9] Courtney ME. Factors associated with the reunification of foster children with their families. Soc Serv Rev 1994; 81-107. [http://dx.doi.org/10.1086/604034]

[10] Faller K, Bellamy C. Mental health problems and child maltreatment. University of Michigan Interdisciplinary Child Welfare Training Program 2000. Available from: http://www.ssw.umich.edu/icwtp/mentalHealth/d-mhpar.pdf

[11] Farmer E, Sturgess W, O’Neill T. The reunification of looked after children with their parents. Patterns interventions and outcomes (Research Brief No. DCSF-RBX-14-08). In: The Department for Children, Schools and Families. London 2008.

[12] Frame L, Berrick JD, Brodowski ML. Understanding reentry to out-of-home care for reunified infants. Child Welfare 2000; 79(4): 339-69. [PMID: 10925764]

[13] Goerge RM. The reunification process in substitute care. Soc Serv Rev 1990; $422-57$. [http://dx.doi.org/10.1086/603780]

[14] Hill M. Inclusiveness in residential child care. In: Chakrabarti M, Hill M, Eds. Residential child care: International perspectives on links with families and peers. United Kingdom: Jessica Kingsley Publishers 2000; pp. 31-66.

[15] Marsh JC, Ryan JP, Choi S, Testa MF. Integrated services for families with multiple problems: Obstacles to family reunification. C Y Serv Rev 2006; 28(9): 1074-87.

[http://dx.doi.org/10.1016/j.childyouth.2005.10.012]

[16] Shook K. Does the loss of welfare income increase the risk of involvement with the child welfare system? C Y Serv Rev 1999; 21(9/10): 781-814. [http://dx.doi.org/10.1016/S0190-7409(99)00054-7]

[17] Choi S, Ryan JP. Co-occurring problems for substance abusing mothers in child welfare: Matching services to improve family reunification. C Y Serv Rev 2007; 29(11): 1395-410. [http://dx.doi.org/10.1016/j.childyouth.2007.05.013] 
[18] Fernandez E, Delfabbro P. Reunification in Australia: insights from South Australia and New South Wales How does foster care work?. England: Jessica Kingsley Publishers 2010; pp. 111-32.

[19] Webster D, Shlonsky A, Shaw T, Brookhart MA. The ties that bind II: Reunification for siblings in out-of-home care using a statistical technique for examining non-independent observations. C Y Serv Rev 2005; 27(7): 765-82. [http://dx.doi.org/10.1016/j.childyouth.2004.12.016]

[20] Sinclair I. Foster Children: Where they go and how they get on. London: Jessica Kingsley Publishers 2005.

[21] Biehal N. Reuniting children with their families: Reconsidering the evidence on timing, contact and outcomes. B J of Soc W 2007; 37(5): $807-23$ [http://dx.doi.org/10.1093/bjsw/bcl051]

[22] Sinclair I, Barker C, Lee J. The pursuit of permanence: a study of the English care system. London: Jessica Kingsley Publishers 2007.

[23] Wade J, Biehal N, Farrelly N, Sinclair I. Caring for abused and neglected children: making the right decisions for reunification or long-term care. London: Jessica Kingsley Publishers 2011.

[24] Ofsted. The voice of the child: learning lessons from serious case reviews. In: A thematic review of Ofstede's evaluation of serious case reviews. London: Ofsted 2010.

[25] Valle IL, Payne L, Jelicic H. The voice of the child in the child protection system. London: NCB Research Centre 2012.

[26] Holland S. Listening to children in care: a review of methodological and theoretical approaches to understanding looked after children's perspective. Child Soc 2009; 23: 226-35 [http://dx.doi.org/10.1111/j.1099-0860.2008.00213.x]

[27] Burr V. Social constructionism. $2^{\text {nd }}$ ed. U.S.A.: Routledge 2003.

[28] Gergen KJ, Warhus L. Therapy as social construction. In: Gergen JK, Ed. Social construction in context. London: SAGE 2001; pp. 96-114.

[29] Witkin SL. An introduction to social constructions. In: Witkin SL, Ed. Social construction and social work practice: interpretation and innovations. U.S.A.: Columbia University Press 2012; pp. 13-37.

[30] Gergen KJ. Relation being beyond self and community. New York: Oxford University Press, Inc 2009.

[31] Sampson EE. Celebrating the other: A dialogic account of human nature. San Francisco: Westview Press 1993.

[32] Hong Kong Government White paper: aims and policy for social welfare in Hong Kong 1965.

[33] Hong Kong Government White paper: social welfare in Hong Kong: the way ahead 1973. Hong Kong: Govt Printer.

[34] Hong Kong Government White paper: social welfare into the 1980s 1979. Hong Kong: Govt Printer.

[35] Hong Kong Government White paper: social welfare into the 1990s and beyond 1991. Hong Kong: Govt Printer.

[36] Social Welfare Department. Residential child care services [online]. Available from: http://www.swd.gov.hk/en/index/site_pubsvc/ page_family/sub_listofserv/id_residchildcare/ [cited 2015a].

[37] Working Group on Development of Residential Child Care Services. Report of the working group on development of residential child care services. Hong Kong: Hong Kong Government 1987.

[38] Social Welfare Department Foster care service [online]. Available from: http://www.swd.gov.hk/en/ index/site_pubsvc/page_family/ sub_listofserv/id_fostercare/ [cited 2015b].

[39] Thoburn J, Ainsworth F. Making sense of differential cross-national placement rates for therapeutic residential care: some takeaway messages from the policy. In: Whittaker JK, deValle JF, Holmes L, Eds. Therapeutic residential care for children and youth. London: Jessica Kingsley Publishers 2015; pp. 37-59.

[40] Social Welfare Department. Main parents'/carers' circumstances leading to the need for out-of-home care n.d.

[41] Labour and Welfare Bureau. Replies to questions raised by finance committee members in examining the estimates of expenditure 2015 - 16 reply serial. Hong Kong. Labour and Welfare Bureau

[42] Social Welfare Department. SWD Review 2010-2011 [online]. Available from: http://www.swd.gov.hk/annualreport/swdreview2011/ eng/ch5_ childwelfare/ index.htmlSource [cited 2016].

[43] Social Weflare Department. SWD Review 2011-2012 \& 2012-13 Hong Kong: Social Welfare Department 2014.

[44] Social Welfare Department. Social Welfare Services in figures. Hong Kong: Social Welfare Department 2015.

[45] Luborsky MR, Rubinstein RL. Sampling in qualitative research: Rationale, issues, and methods. Res Aging 1995; 17(1): 89-113. [http://dx.doi.org/10.1177/0164027595171005] [PMID: 22058580]

[46] Hammersley M. Recent radical criticism of interview studies Any implications for the sociology of education. B J Soc of Ed 2003; 24(1): 119-26.

[47] Harris SR. Studying equality/inequality: Naturalist and constructionist approaches to equality in marriage. J C Ethno 2003; 32 (2): 200-32. [http://dx.doi.org/10.1177/0891241602250886]

[48] Seale C. Qualitative interviewing. In: Seale C, Ed. Researching society and culture. London: SAGE 1998; pp. 202-16. 
[49] Rose G. Visual methodologies: An introduction to researching with visual materials. $2^{\text {nd }}$ ed. Thousand Oaks, CA: Sage 2007.

[50] Riessman CK. Narrative analysis. California: Sage Publications, Inc 1993; Vol. 30.

[51] Clandinin DJ, Connelly FM. Narrative inquiry: Experience and story in qualitative research. San Francisco, CA: Jossey-Bass 2000.

[52] Colyar J, Holley K. Narrative theory and the construction of qualitative texts. In: Savin-Boden M, Major CH, Eds. New approaches to qualitative research: Wisdom and uncertainty. London: Routledge 2010; pp. 70-9.

[53] Lieblich A, Tuval-Mashiach R, Zilber T. Narrative research: Reading, analysis, and interpretation. Thousand Oaks, CA: Sage 1998.

[54] Attride-Stirling J. Thematic networks: an analytic tool for qualitative research. Qual Res 2001; 1(3): 385-405. [http://dx.doi.org/10.1177/146879410100100307]

[55] Rubin A, Babbie E. Research methods for social work. $8^{\text {th }}$ ed. U.S.A.: Brooks/Cole 2014.

[56] Docherty S, Sandelowski M. Interviewing children. Res Nurs Health 1999; 22(2): 177-85. [http://dx.doi.org/10.1002/(SICI)1098-240X(199904)22:2<177::AID-NUR9>3.0.CO;2-H] [PMID: 10094302]

[57] Zajac R, Hayne H. I don't think that's what really happened: the effect of cross-examination on the accuracy of children's reports. J Exp Psychol Appl 2003; 9(3): 187-95. [http://dx.doi.org/10.1037/1076-898X.9.3.187] [PMID: 14570512]

[58] Chao R, Tseng V. Parenting of Asian. In: Bornstein MH, Ed. Social condition and applied parenting. London: Lawrence Erlbaum Associates Publishers 2002; 4: pp. 59-93.

[59] Hessle S. Child welfare on the eve of the twenty first century: what we have learned. In: Callahan M, Hessle S, Strega S, Eds. Valuing the field: child welfare in an international context. England: Ashgate Publishing Limited 2000; pp. 3-22.

[60] Moss P, Petrie P. From children's services to children's spaces: Public policy, children and childhood. London: Routledge Falmer 2002.

[61] Moss P, Petrie P. Children - who do we think they are. In: Hendrick H, Ed. Child welfare and social policy. United Kingdom: The Policy Press 2005; pp. 85-106.

[62] Lam CM. Not grown up forever. New York: Nova Science Publishers 2007.

[63] Irving F, Hewitt P. The law in relation to children. In: Hewitt P, Ed. Family law and practice in Hong Kong. Hong Kong: Sweet \& Maxwell 2011; pp. 279-301.

[64] Region HK. Hong Kong Special Administrative Region. Report of the Hong Kong Special Administrative Region under the Convention on the Rights of the Child 2003. Available from: http://www.legco.gov.hk/yr03-04/english/.../ha/.../ha0611cb2-childrpt-e-scan.pdf

[65] Fernandez E. Significant harm: unravelling child protection decisions and substitute care careers of children: perspectives of child welfare workers and biological parents. England: Avebury Ashgate Publishing Ltd 1996.

[66] Chan KL. Policies and social services related to children protection. In: Chan KL, Ed. Child protection in Chinese societies. New York: Nova Science Publisher, Inc. 2012; pp. 145-72.

[67] Kid's Dream [online]. Available from: http://kidsdream.org.hk/v2/web/plain.php?page=a_kdintro1\&lang=en [cited 2015].

[68] Hong Kong Special Administrative Region. Kid's dream in Hong Kong Children's report to the UN Committee on the right of the child under the CRC. Hong Kong: Hong Kong Special Administrative Region 2012.

[69] Ip P. Children's rights in hospital. Conference proceedings of 1993 and 1995 on children's rights in Hong Kong. 9 In: Hong Kong Committee on Children's Rights and Against Child Abuse 1997; pp. 144-5, 187-95.

Received: December 24, 2015

Revised: February 8, 2016

Accepted: February 15, 2016

(C) Mooly M. Wong; Licensee Bentham Open.

This is an open access article licensed under the terms of the Creative Commons Attribution-Non-Commercial 4.0 International Public License (CC BY-NC 4.0) (https://creativecommons.org/licenses/by-nc/4.0/legalcode), which permits unrestricted, non-commercial use, distribution and reproduction in any medium, provided the work is properly cited. 